\title{
IMPROVING THE LAE-LAE ISLAND ENVIRONMENT AND SETTLEMENT QUALITY AS A MARINE TOURISM DESTINATION IN MAKASSAR CITY
}

\author{
Idawarni Asmal \\ Architecture Departement, Engineering Faculty, Hassanudin University, Indonesia \\ Email : idawarniasmal@yahoo.com
}

\begin{abstract}
Lae-Lae is an island in the city of Makassar, Indonesia. The island area of 0.04 sqkm, inhabited by 420 families or about 1780 inhabitants, is located $1.5 \mathrm{~km}$ from Makassar and accessible in 10 minutes with a fishing boat from the city of Kayu Bangkoa port. Lae-Lae island has excellent potential for tourist development of Makassar city, and a paradise for fans of sunset. In addition, there are also historical sites of war comprising an underground tunnel, which was said to connect to the fortress city of Makassar / Fort Rotterdam. Conditions of Lae-Lae island today feel less than comfortable because of the condition of the heat and lack of shade to enjoy the sunset. In addition, the attractions offered are also still very poor compared with its potential. Another thing deemed less supportive of Lae-Lae as a tourist destination in the past was the condition of facilities. To improve the quality of Lae-Lae island as a tourist destination, it would be necessary to arrange development of new tourist objects and improvement in the attractions that already exist. So the potential of the island as a travel destination can be optimized. The goal was to plan the arrangement of Lae-Lae island, both the environmental aspects and the settlement, so that Lae-Lae can be an optimal attraction for fans of nautical tourism, both locally and internationally. The method used was direct observation in the field through recordings, interviews, and of the conditions that exist today, which would then be linked to theories, concepts, and literature, also field trip to other tourist attractions that are more advanced. Results were in the form of settlement planning and Lae-Lae island environmental improvement that would be safe, comfortable and of tourism value.
\end{abstract}

Keywords: Marine tourism, Lae-lae island, Settlement. 


\section{INTRODUCTION}

Lae-Lae Island administratively belongs to the territory of Makassar, Ujung Pandang sub-district. It is a small island in the Spermonde archipelago, South Sulawesi. The wide island is \pm 8.9 ha. The island is $1.5 \mathrm{~km}$ from kayu bangkoa Makassar pier and can be reached by speedboat in less than 15 minutes from the dock. The island is high density and inhabited by \pm 1727 , consisting of 865 men and 862 women in 354 families (Central Bureau of Statistics of Makassar 2014, and BPS Makassar City, 2013).

Lae-Lae Island is actually a natural barrier for Makassar City. The Japanese government made a sea wall that extends on the northern part of the island, about $100 \mathrm{~m}$. This gradually underwent sedimentation mainly on the west area of the sea wall and then formed a beach; additionally the Indian government also built a sea wall around the island, and today this has become the main road on Lae-Lae island.

The Island has potential to serve as a tourist destination, both for nature and culture tourism. From the aspect of nature, the location and the beauty of the island form a tourist asset, and people's lives and modest livelihood as fishermen can also prove interesting for foreign tourists who want to see the daily life of island society. But these aspects have not been optimally styled and so look sober and less attractive. Based on observations, few tourists are visiting the island. On a typical day visitors number only around 10 to 15 people per day, while on a holiday or school holiday season the number of visitors increased, but not significantly, to only around 20-30 people per day. The favorite place visited was in the northern part of the island, a white sandy beach. To increase tourist visits to the Lae-Lae island, it is necessary to reorder the island in various aspects, both nature and inhabitants.

The purpose of the study was to plan the arrangement / structuring of Lae-Lae island, in both environmental aspects and the housing, so that Lae-Lae can attract tourists both local, national and international levels.

The method used was direct observation of the field through recordings, interviews, and "feeling" the conditions that exist today, which would then be linked to theories, concepts, and literature / field trip to other tourist attractions that are more advanced.

\section{THEORY / RESEARCH METHODS}

Tourism is the term given when someone travels, making a trip and covering the activities and events that occur when a person is traveling (Sutrisno, 1998, p: 23 in Yuliani, 2013). Tourism can be briefly defined as the activity in the community related to the rating (Soekadijo, 2000, p: 2 in Yuliani, 2013) Tourism is an integral part of human life, especially regarding social and economic activities. According to Pendit (1994), there are several types of tourism that are already known, namely:

1. Culture tourism,

2. Health tourism,

3. Sports tourism,

4. Commercial tourism, 
5. Industry tourism,

6. Marine Tourism,

7. Nature Reserve tourism,

8. Honeymoon tourism,

Based on the division of the tourism types in Lae-Lae island, there are two types of tourism that can be developed, namely culture and nature. Nature tourism is a form of leisure activity and tourism utilizing natural resources, both in the natural state or after cultivation, thus allowing tourists to acquire freshness both physical and spiritual, also to gain knowledge and experience as well as inspiration and love for nature (Anonymous, 1982 in Saragih, 1993). Culture tourism will comprise trips taken on the basis of a desire to expand the view of a person's life by organizing visits to other places, studying the situation of the people, habits and customs, a way of life, their culture and art (Pendit, 1994).

One type of nature tourism which is now undertaken by many local and foreign tourists is marine tourism, which can be interpreted as covering nature and related to water resources. It could also be explained that the activities of nautical tourism mean travel to enjoy the sea (Arison, Akhmad, 2006).

Marine tourism is a kind of special interest tourism which has activities related to the marine environment, as well as above the surface of the sea (marine), and below the surface of the sea (submarine). According to the Directorate General of Tourism, marine tourism is also a form of tourism travel to visit a place because it has a special interest or purpose as an object or an activity that could be seen or done on location or at a specific tourist destination (the ministry in 2004). Marine tourism is eco-tourism based on the attractiveness of maritime locations or areas that are predominantly aquatic or marine (PRWLSDNH 2002). Types of marine tourism activities include: (1) sun bathing at the beach or pool; (2) ocean or freshwater swimming; (3) beachside and freshwater sports such as water scooter, sausage boat, water tricycle, wind surfing, surfboarding, paddle board, parasailing, catamarans; (4) pleasure boating; (5) ocean yachting; (6) cruising; (7) fishing; (8) diving, snorkeling, glass boat viewing and underwater photography; (9) marine parks; (10) canoeing; and (11) coastal parks, wild life reserves, rain forest, gardens and trails, fishing villages (Dahuri, 1996).

\section{Lae-Lae Settlement Conditions}

Settlement area is part of the environment outside protected areas, whether urban and rural, that serves as a neighborhood or residential environment and where activities support life and livelihood (UU RI No 1, 2011). Similarly, on the island of Lae-Lae there are fishermen's settlements with various activities conducted by the residents. In addition to residential activity, Lae-Lae is also one of the tourist destinations in the city of Makassar. The illustration of Lae-Lae island can be seen in Figure 1. 


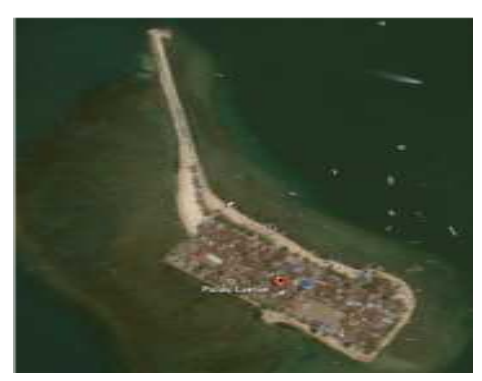

Figure 1. Lae-Lae Island

In their daily life, people on the island of Lae-Lae spend more time in open spaces. Various activities do not take place in the house but in the yard, the street, beaches, and other open places. Diverse activities are conducted in these places, where there are playing, working, resting, eating, parenting, or just socializing with neighbors. In these places, they put bale-bale as seats and the placement is generally under the big tree.

The beach area is a communal space that is used as a parking lot for boats, manufacture and maintenance of boats / ships, for play, to socialize, for exercise, recreation, and even control the environment that might be affected by newcomers. There are several bale-bale in the area, almost all of them placed near the trees to get shade and fresh air. The illustration of communal space in Lae-lae island can be seen in Figure 2.

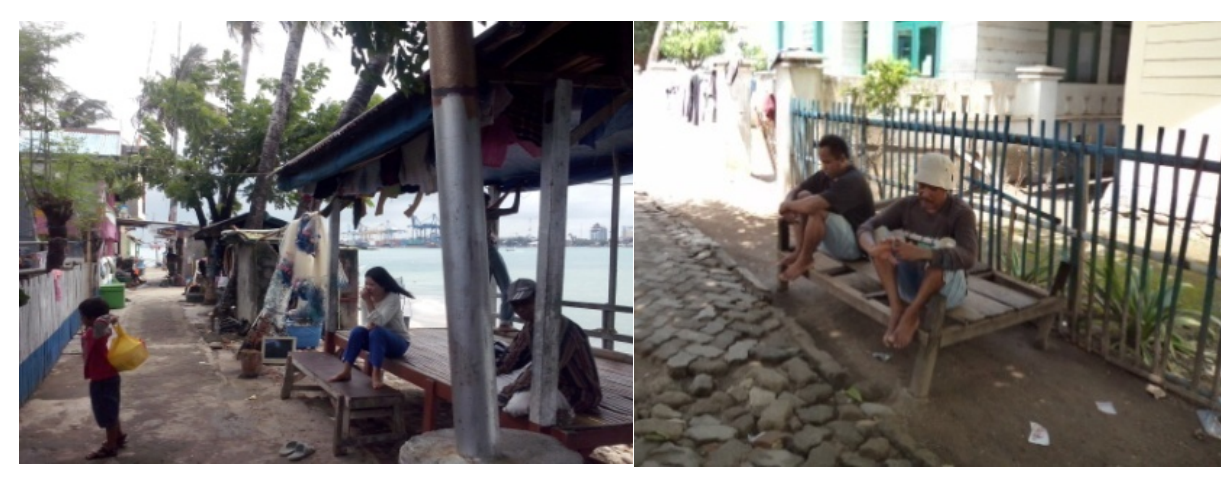

Figure 2. Communal Space Created by the Street Side

This happens because of limited land on Lae-Lae island while the population continues to grow and the need for residential space increases. also for other activities that support life and livelihood. The green open space and the football field in Lae-Lae island can be seen in Figure 3. 


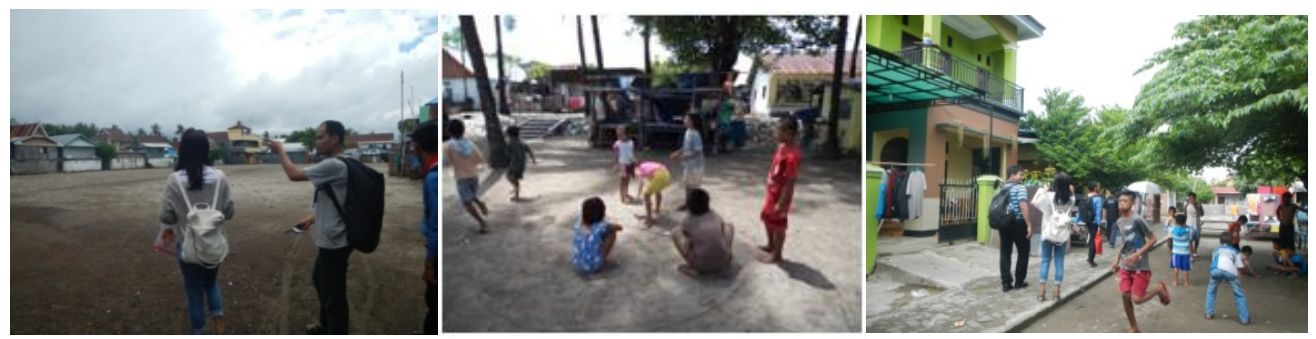

Figure 3. Football Field and Green Open Spaces

\section{Attractions for Tourism that Exist Today in Lae-Lae Island}

Currently, there are tourist attractions which are north of the island. Originally the area was a seawall intended for the protection of the Makassar city from the surf. Over the years, the west area of the seawall has experienced sedimentation and developed into the beach and is currently visited by many residents for recreation. There are several buildings made of bamboo lining the place and used by tourists for resting. Similarly, the row of tammamate trees / Jawa-jawa are giving shade and a comfortable atmosphere in the area. The illustration of sea wall which had been developed and the row of tammamate trees can be seen in Figure 4.

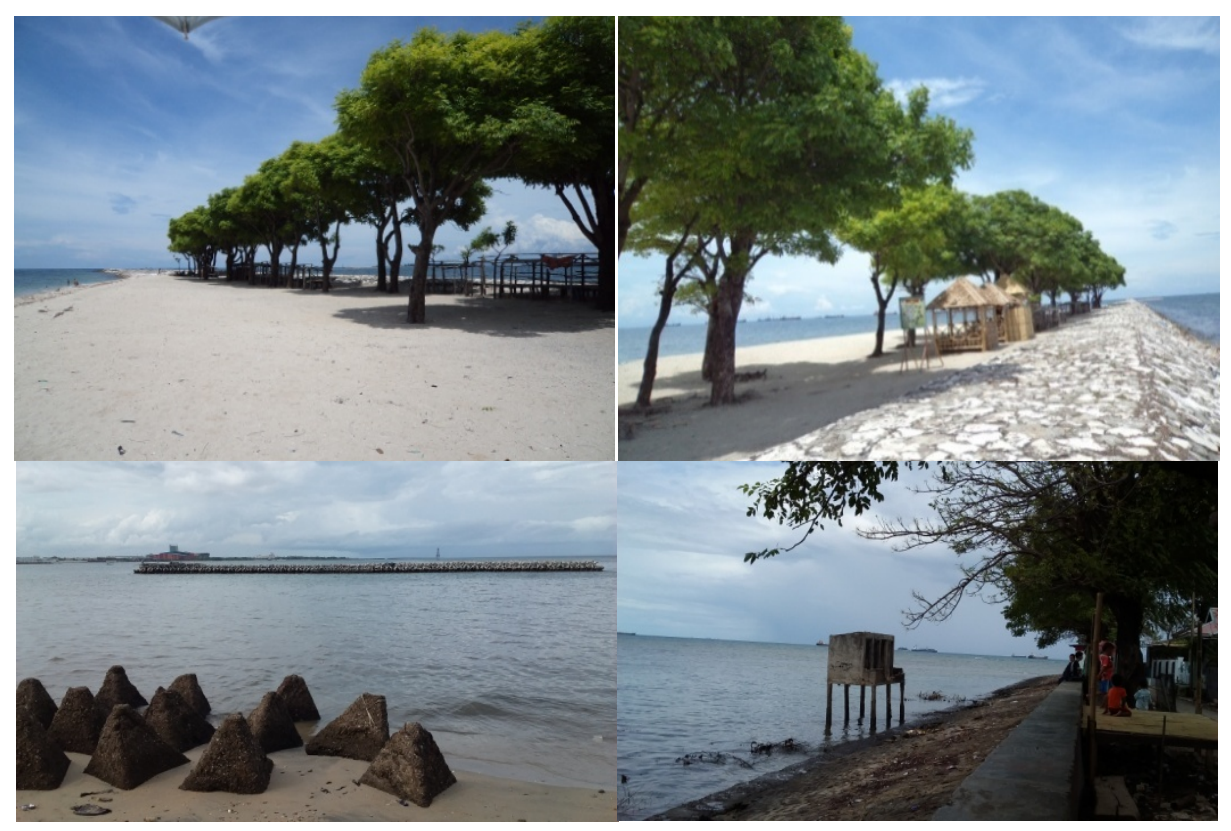

Figure 4. Sea Wall Which Developed into a Recreational Beach and the Row of Tammamate Trees 


\section{RESULTS AND DISCUSSION}

To optimize the tourism potential of Lae-Lae island mainly as a marine tourism resource, it is necessary to develop tours in the area, namely for fishing, diving, beach sports, culture and heritage tourism. Pedestrian sign are needed. Here lie the places that can be developed for the purpose of tourism on Lae Lae island. The area that can be developed as a tourist attraction in Lae-Lae island can be seen in Figure 5.

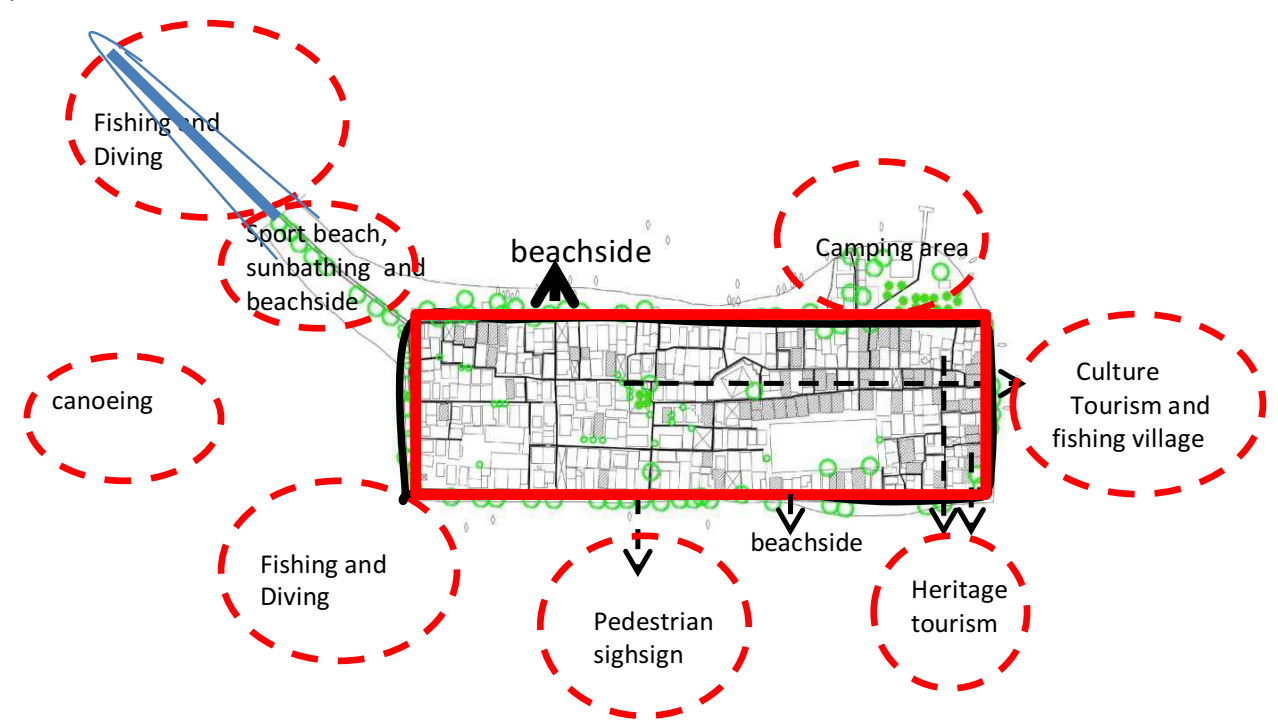

Figure 5. The Areas that can be Developed as a Tourist Attraction in Lae-Lae Island

Fishing and diving are activities favored by tourists. On Lae-Lae island this can be done on the north-western the island. This section is quiet and there is very little activity of the residents in this area. At the front, it contains the sea wall, located in shallow waters and which becomes a breakwater so the waves are quieter, and it facilitates the growth of coral reefs. In the near area, there is also a concrete breakwater that had been used as a seat for anglers. Fishing has many benefits, such as a hobby, health benefits, treating stress, exercising patience and concentration / focus.

Sport. Beach sports activities such as beach volleyball can be done on the beach located at the northern shore of the island, in addition to the wide beaches that allow for these activities, the atmosphere is quiet and away from neighborhoods and there is the availability of bale-bale as a resting place to support these activities.

Camping area. These activities can be carried out in the eastern part of the island near from the main gate because it has a land area that is quite spacious and shaded by the palm trees (see Figure 6). 

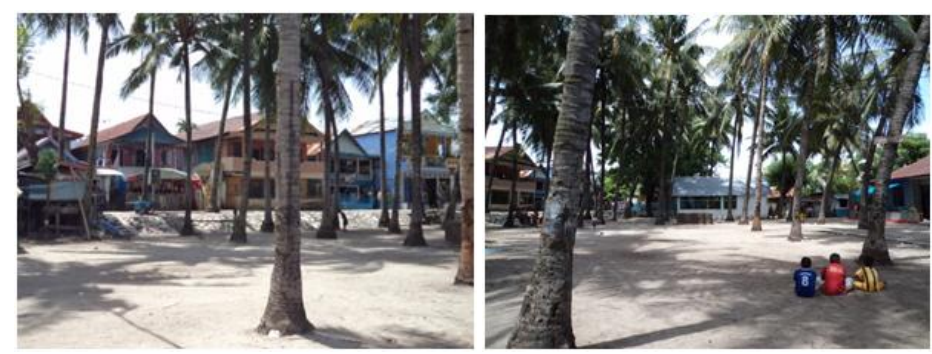

Figure 6. Green Open Space Used as a Playground and Camping Area

Pedestrian signs are planned with the aim of enjoying the beauty of the beach and enjoying the sunset and sunrise while cycling or walking around the island. A beautiful view of the ocean with the roar of the waves always provides peace and comfort, especially for elderly tourists (Maryani, 2008). This is a kind of nature tourism or eco-tourism, to a place where nature is relatively undisturbed or contaminated (polluted) with the objective of studying, admiring and enjoying the scenery, vegetation and wildlife, as well as forms of cultural manifestations, both from the past and the present (Hani, et al 2010)

Tourism can be developed on Lae-Lae island by managing dikes that surround the island. Currently, the embankment is used as a public road for the community. His condition is alarming, as some parts have been damaged and there are memorable slums and arid land. So that the dike can give the impression of a comfortable, attractive, and safe place, it should be on the outer side of the embankment bordering the highest tides and given a guardrail of corrosion-resistant materials or vegetation. These can be combined with hard and soft materials, being on the side of it other than by drainage channel to smooth the sewerage system so as not flooded, are also planting and arrangement of vegetation, and making coastal set back (withdrawal of buildings from the coast). A coastal set back attempts to provide space for vegetation to flourish and for safety against a possible increase in the highest tide. At certain distances, resting areas can be created, serving as a means of interaction of citizens and to enable them to enjoy the sea view. The resting places can be made by building stages that juts into the sea, so as not to interfere with the activity on the shoulder of the road or on the road. The building can be like a pergola with vines so for those who sit under it to feel comfortable and shady.

On the roadside, many established bale-bale that look shabby should be removed and returned to their original function. This area should be planted with trees. Re-structuring these areas will provide many positive effects for the environment and for the inhabitants of the island, which include improving the quality of comfort, safety, beauty, and economy. It also can be a habitat for wild animals.

Culture and heritage tourism. More than simply visiting historic sites, heritage tourism is a personal encounter with traditions, history, and culture. Heritage tourism is based on the concept that each community has a story to tell. This is a rapidly growing niche market that is directed towards experiencing the 
local customs, traditions, arts, history, sites, and culture that authentically represent a particular place. To the heritage tourist, this culture must be unique and it must be authentic. The heritage tourist wants to visit historic house museums, courthouses, battle fields, gardens, light houses, Native American and presidential sites, along with revitalized historic waterfronts, downtown districts, and residential neighborhoods (Burns et al, (2010).

Lae-Lae Island can also be developed for culture and heritage tourism, where the tourism can see and feel the state of the masses, habits, and customs, way of life, culture and art of the local people, besides the places that are considered sacred, called saukang, and caves. The Japanese caves in Lae-Lae island can be seen in figure 7.

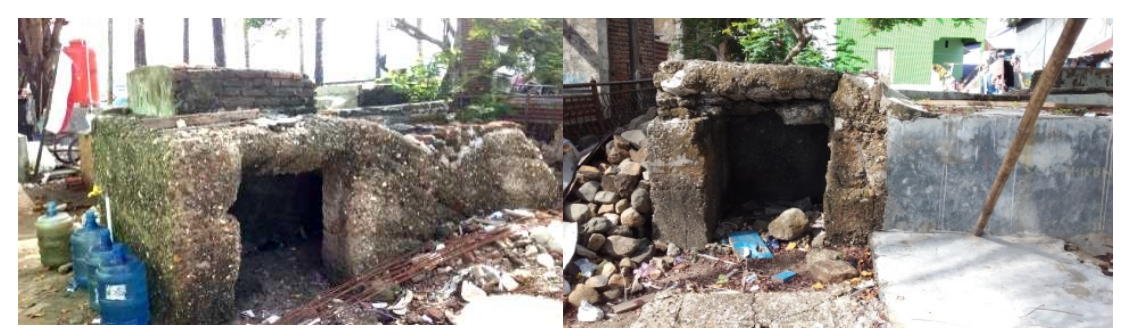

Figure 7. Japanese Caves as Cultural Heritage Tourism

In another part of the island, there is a Japanese cave which according to citizens' information was a Japanese relic cave, providing a passage to the mainland of Makassar city. But the condition of the cave is very poor, as it was used as a garbage dump by the local people. These items can be developed for heritage tourism. The illustration of social life and culture tourism can be seen in figure 8 , while the nature tourism can be seen in figure 9 .

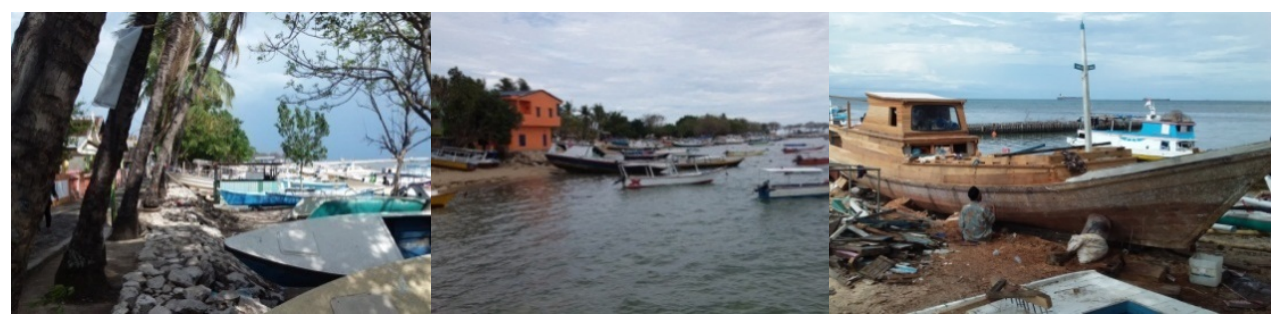

Figure 8. Social Life and Culture Tourism 


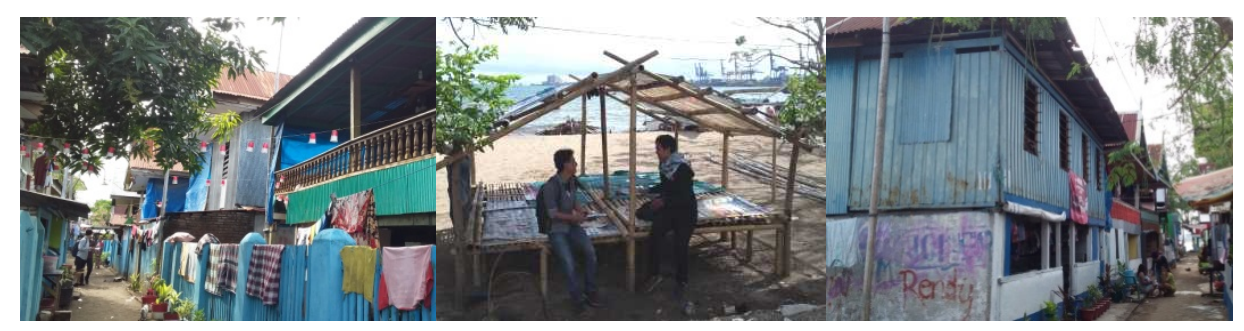

Figure 9. Nature Tourism

The Japanese cave has historical value. Based on research conducted by PATA in 1961 in North America, for more than 50\% of foreign tourists who visit the Asia and Pacific regions, the motivation of their travel is to look and see the customs, the way of life, historical heritage, ancient buildings and buildings of high value. According to the study Tourism Citra Indonesia in 2003, cultural tourism is the element that most attracts foreign tourists to come to Indonesia. Getting a score of 42.33 foreign tourists placed culture in the category of 'very interesting' and on top of other elements such as natural beauty and historical heritage, with a score of 39.42 and 30.86 respectively. This demonstrates cultural attractions as the most favored by tourists from tourism in Indonesia. Therefore, the condition of this Japanese cave needs to be re-organized to make it more attractive

Besides the places mentioned above needing to be developed, the network facilities and another infrastructure are also very directly related to the purpose of the tours, including the piers, the access from the dock to the settlement as well as homestay. As expressed by Middleton, from a marketing standpoint, the tourism industry is divided into five components: attractions, accommodation, transport, travel organizers and the tourism organization (Astina, 2010).

Development and improvement of tourist resources is not only a duty of the government, but the involvement of local communities is very important. Their involvement may include the provision of transport, guide, accommodation, and craft products. Their involvement is very beneficial for the environment and for society.

\section{CONCLUSIONS}

Based on the above discussion, it is necessary to structure and development tourist objects that exist on the Lae-Lae island as optimally as possible in order to attract more visitors to the island. Additionally, facilities and infrastructure must also be improved to provide convenience, comfort, and safety to the visitors to enjoy their tourist activities. 


\section{REFERENCES}

Transportasi Indonesia-Kamboja Workshop-Seminar Transportation between Indonesia-Cambodia.

Dahuri, Rokhmin, dkk. (1996), Pengelolaan Sumberdaya Wilayah Pesisir dan Lautan Secara Terpadu. Jakarta : PT. Pradnya Paramita

Maryani, E. (2008), Penataan Ruang Wisata Pantai. Makalah disajikan dalam pertemuan Scientific Meeting di bali dengan tema perubahan iklim global 1819 maret 2008.

Hani et al (2010), Potensi Wisata Alam Pantai-Bahari, PM PSLP PPSUB Agustus 2010 (diunggah http://marno.lecture.ub.ac.id/files/2011/12/Analisis-PotensiWisata-Alam-Bahari.Pdf)

Astina, I.B.K. (2010), Analisis pariwisata, Fakultas Pariwisata, Universitas Udayana . Vol. 10, No. 1, 2010. Issn 14103729.

Burns, L. et al. (2010), Heritage Tourism Handbook: A How-to-Guide for Georgia.

Yulius, et al (2014), Penentuan Kawasan Wisata Bahari di P.Wangi-Wangi dengan Sistem Informasi Geografis.

Pendit, N. S. (1994), Ilmu Pariwisata: Sebuah Pengantar Perdana. Jakarta: Pradnya Paramita.S

Yuliani, (2013), Strategi Komunikasi Dinas Kebudayaan Pariwisata dan Kominfo ( Disbudpar ) Dalam Meningkatkan Kunjungan Wisatawan Di Desa Pampang Kota Samarinda. eJournal llmu Komunikasi, 2013, 1 (3): 450-464 ISSN 0000-0000, ejournal.ilkom.fisip-unmul.ac.id (C) Copyright 2013

Undang-Undang Republik Indonesia Nomor 1 Tahun 2011 Tentang Perumahan dan Kawasan Permukiman

https://rokhmindahuri.wordpress.com/category/resouces-based.../wisatabahari

(https://id.wikipedia.org/wiki/Pariwisata_berbasis_budaya). 